\title{
Magnetic resonance imaging of the live tri-spine horseshoe crab (Tacbypleus tridentatus)
}

\author{
Изучение анатомии жкивого мечехвоста Tacbypleus tridentatus \\ при помощи магнитного резонанса
}

\author{
Adams Hei Long Yuen ${ }^{1,}$, Derek Hang Chun Kwok ${ }^{2}$, Sang Wha Kim ${ }^{3}$

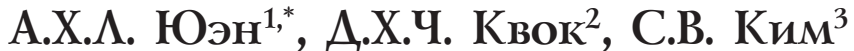

\footnotetext{
${ }^{1}$ Department of Diagnostic Radiology and Clinical Oncology, Li Ka Shing Faculty of Medicine, The University of Hong Kong, Pokfulam, Hong Kong.

${ }^{2}$ Time Medical Systems, Science Park West Avenue, Hong Kong Science Park, Shatin, New Territories, Hong Kong.

${ }^{3}$ Laboratory of Aquatic Biomedicine, College of Veterinary Medicine, Seoul National University, Seoul 08826, Republic of Korea.

*Corresponding author: E-mail: yhladams@hotmail.com
}

KEY WORDS: imaging anatomy; magnetic resonance imaging; tri-spine horseshoe crab.

КЛЮЧЕВЫЕ СЛОВА: анатомия, магнитный резонанс, мечехвост Tachypleus tridentatus.

ABSTRACT. Tri-spine horseshoe crab (Tachypleus tridentatus) is one of the most extensively studied arthropods from both biological and paleontological perspectives due to its unique suite of anatomical features and as a useful modern analogue for fossil arthropod groups. To assist the study and documentation of this iconic taxon, thorough understanding of their anatomy is necessary. Traditional dissection approach to study the anatomy of tri-spine horseshoe crab is technically demanding and time-consuming, and causes loss of specimen integrity. Magnetic resonance imaging (MRI) have currently become more readily available for zoomorphological investigation. A growing body of digitally stored anatomical data has become available to assist with biological, morphological and pathological investigation, without destroying specimens. The objective of the present study is to provide an overview of the normal cross-sectional anatomy of the live tri-spine horseshoe crab using T1W and T2W MRI, along with dissection images. MRI scan of 4 living tri-spine horseshoe crabs were performed by $1.5 \mathrm{~T}$ MRI scanner. The resulting images provided excellent detail of major anatomical structures of live tri-spine horseshoe crabs. The illustrations in the present study provides an initial reference to evaluate anatomical structures of the trispine horseshoe crab on MR images.

How to cite this article: Yuen A.H.L., Kwok D.H.C., Kim S.W. 2019. Magnetic resonance imaging of the live tri-spine horseshoe crab (Tachypleus tridentatus) // Arthropoda Selecta. Vol.28. No.2. P.247-251. doi: 10.15298/arthsel. 28.2.06

РЕЗЮМЕ. Благодаря уникальному набору анатомических особенностей и наличием современных аналогий вымершим группам артропод мечехвост Tachypleus tridentatus - одно из наиболее интенсивно исследованных членистоногих, как с био- логической, так и с палеонтологической точки зрения. Для лучшего понимания этого таксона-иконы необходимо детальное исследование его анатомии. Традиционный анатомический подход, связанный с расчленением объекта, технически затруднителен и занимает много времени, при потере целостности образца. В настоящее время для зооморфологических исследований все чаще применяют магнитный резонанс (МР). Растущий объем оцифрованных анатомических данных доступен для биологических, морфологических и патологических исследований, которые можно проводить без разрушения объектов. Цель настоящей работы - на серии последовательных срезов дать обзор анатомии живого мечехвоста, используя T1W и $\mathrm{T} 2 \mathrm{~W}$ МР-изображения в сравнении с обычными срезами. МР-сканирование 4 живых мечехвостов было выполнено при помощи 1.5T МР-сканера. Совмещенные изображения показывают точные детали основных анатомических структур мечехвоста и позволяют дать первые оценки качества МР-изображения этого членистоногого.

\section{Introduction}

Tri-spine horseshoe crab (Tachypleus tridentatus (Leach, 1819)) is one of the most extensively studied arthropods from both biological and paleontological perspectives due to its unique suite of anatomical features and as a useful modern analogue for fossil arthropod groups. To assist the study and documentation of this iconic taxon, thorough understanding of their anatomy is necessary.

The internal and external anatomical structures of euthanized or died horseshoe crab were studied repeatedly since nineteenth centuries and are regularly depicted in scientific literatures using dissection approach 
[Van der Hoeven, 1838; Ward, 1969; Dewey et al., 1973; Silvey, 1973; Bergdale, 2017]. This traditional procedure is technically demanding and time-consuming, and causes loss of specimen integrity. Cross sectional imaging technique, such as computed tomography (CT) and magnetic resonance imaging (MRI), have become more readily available for zoomorphological investigation. A growing body of digitally stored anatomical data has become available to assist with biological, morphological and pathological investigations. Recently, Bicknell and his team made use of CT and micro-CT to study the appendages and muscles of the horseshoe crab with iodine staining [2018]. However, iodine staining of the animals in the study requires killing of the animals. MRI measures the distribution of hydrogen atoms within the specimen and is specifically used to reveal internal soft tissue structures with subtle differences in composition [Lauridsen et al., 2011], without destroying the specimen. Spatial relationship between anatomical structures can then be investigated in situ in their true dimensions [Lauridsen et al., 2011; Berquist et al., 2012].

Planimetric MR images are frequently used for the study of anatomical structures in many aquatic invertebrates, including blue crab [Brouwer et al., 1992], crayfish [Herberholz et al., 2005], fresh water mussel [Michael Holliman et al., 2008], oyster [Pouvreau et al., 2006; Smith, Reddy, 2012], squid [Ziegler et al., 2011], starfish [Sigl et al., 2013] and urchin [Ziegler et al., 2008]. To date, there is no scientific literature describing MRI anatomy of the live tri-spine horseshoe crab to the best of the authors' knowledge. The objective of the present study is to provide an overview of the normal cross-sectional anatomy of the live trispine horseshoe crab using MRI, along with dissection images.

\section{Materials and Methods}

Four live specimens of tri-spine horseshoe crabs ( $\mathrm{Ta}$ chypleus tridentatus) (2 males and 2 females) were obtained commercially from Hong Kong. The animals used in the present study ranged from 43 to $48 \mathrm{~cm}$ in length from the front of the carapace to base of the telson.

Living tri-spine horseshoe crabs were used for the study of anatomical structures in the present MRI study. In the event that the animal is active, the MR images may subject to motion artifacts (e.g. blurring), which may degrade image quality and lead to misinterpretation of anatomical structures [Havsteen et al., 2017]. In the present study, sedation was achieved by removing the tri-spine horseshoe crabs from water for 15 minutes prior to handling and imaging. This technique required no chemical agents and was reported to be effective in sedating horseshoe crab without apparent physiologic harm [Nolan, Smith, 2009].

The whole-body MRI scans were performed using a 1.5 Tesla (T) MRI scanner (Panion Premier, Time Medical Systems, Hong Kong, China) equipped with a
$60 \mathrm{~cm}$ bore with full $45 \mathrm{~cm}$ field-of-view (FOV) imaging capability. The actively shielded gradient coils have gradient strength of $34.4 \mathrm{mT} / \mathrm{m}$ with a maximum slew rate of $123 \mathrm{~T} / \mathrm{m} / \mathrm{s}$ and a rise time of $280 \mu \mathrm{s}$. A 16channel multi-purpose coil was used to receive the signal using fast low angle shot sequences in T1-weighted modes (T1W) and fast spin echo sequences in T2weighted modes (T2W). MR protocol: echo time [TE] $8.2 \mathrm{~ms}$; repetition time [TR] $19.6 \mathrm{~ms}$; bandwidth 35.7 $\mathrm{kHz}$; flip angle $30^{\circ}$, and FOV $260 \times 300 \mathrm{~mm}$ were selected to acquire $\mathrm{T} 1 \mathrm{~W}$ images with reconstructed spacing $0.29 \times 0.29 \mathrm{~mm}$, in which lipids and proteinaceous fluids were enhanced. MR protocol: TE 133.5 ms; TR $6300 \mathrm{~ms}$; bandwidth $35.7 \mathrm{kHz}$; flip angle $90^{\circ}$, and FOV $260 \times 300 \mathrm{~mm}$ were selected to acquire T2W images with reconstructed spacing $0.29 \times 0.29 \mathrm{~mm}$, in which signals from loosely bound protons (e.g., fluids) were enhanced. Scan time and slice thickness was 20 minutes and $3 \mathrm{~mm}$ respectively for both sequences. MRI scans in coronal planes were obtained using open-source Digital Imaging and Communications in Medicine viewer software (Horos Project, 2015, version 2.1.0; www.horosproject.org). Seven section levels were selected. Figure 1 depicts the slicing levels and numbering of subsequent figures. The images were reviewed by radiological clinician (AY) and veterinarian (SWK).

One female tri-spine horseshoe crab was dissected. Identification of anatomical structures was aided by existing published figures of horseshoe crab anatomy [Ward, 1969; Dewey et al., 1973; Silvey, 1973; Watson, 1980; Spotswood, Smith, 2007; Bergdale, 2017]. Corresponding dissection images were chosen trying to identify the best anatomical correlation for MR images.

\section{Results}

Anatomical structures of the live tri-spine horseshoe crab were identified on the MR images and correlated with corresponding dissection images. The results of the present study were shown in Figures $2 \mathrm{a}-\mathrm{g}$, corresponding to ventral to dorsal progression.

T1W and T2W coronal MR images of the live trispine horseshoe crab provided detail of anatomical structures and correlated well with corresponding dissection image. Excellent discrimination of soft tissues, organs and cavitary structures containing fluids was evident in the T2W MR images. These structures include: major muscles; circulatory system structures including the heart, pericardial cavity and major arteries; digestive system structures including the crop, gizzard and esophagus; excretory system structures including the convoluted tubule; nervous system structures including the optic nerves, protocerebrum and tritocerebrum. T1W MR image provides the best contrast and excellent definition for morphology of digestive tract, including pyloric valve, midgut, hindgut and rectum. As described in other invertebrate [Köhnk et al., 2017], mineralized tissues such as the exoskeleton were hard- 


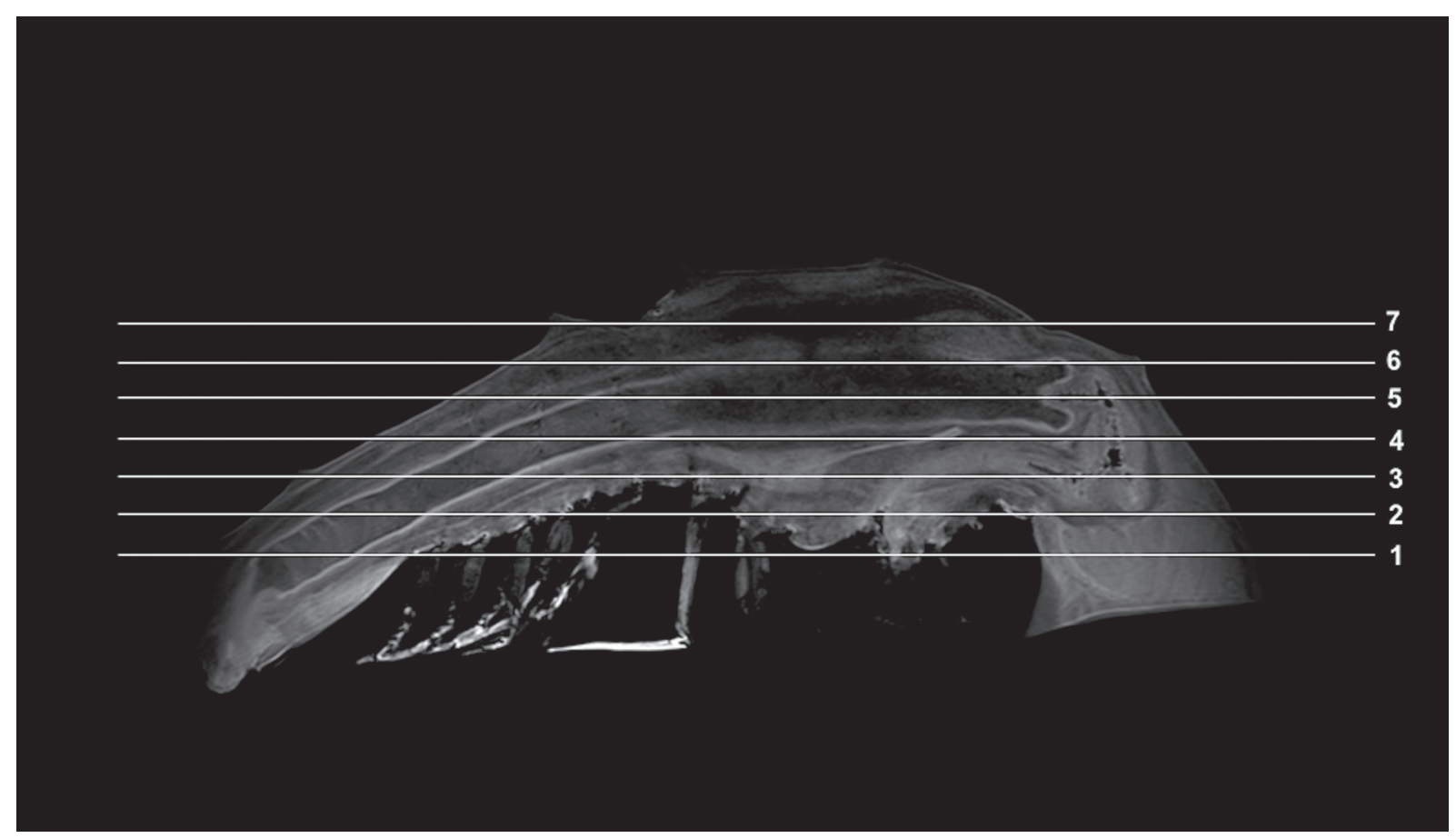

Fig 1. Mid sagittal view of Tachypleus tridentatus by MRI scans; showing coronal sectioning levels corresponding to Fig. 2.

Рис. 1. Срединный сагиттальный вид мечехвоста Tachypleus tridentatus, с указанием коронального сканирования при помощи магнитного резонанса, обозначения срезов соответствуют иллюстрациям на рис. 2.

ly recognizable by MRI since it does not provide sufficient MR signal.

\section{Discussion}

The present study focused on the application of MRI to study the anatomical structures of the live trispine horseshoe crab. The results demonstrated that major anatomical structures of the live tri-spine horseshoe crab can be identified with a 1.5T MRI scanner. Adequate image resolution and contrast were achieved without specialized coils, software, or excessive scan time. Euthanasia of the tri-spine horseshoe crab in the present study is not required. Although Tachypleus tridentatus was the Xiphosura evaluated in the present study, it is likely that the MR protocols used in the present study will be applicable to other live horseshoe crab species of similar size. MRI significantly increase the quality and quantity of anatomical and morphological information. Detailed anatomical structures, presented in the present study using MRI, validate this imaging technique for suitable evaluation of multiple organ systems in the live tri-spine horseshoe crab.

Horseshoe crab collections housed in various institutions and museums, possess a wealth of anatomical and morphological data that have academic, cultural and historic value. Using traditional dissection for examination purpose will irretrievably alter or even destroy the specimen and preclude other fresh analysis on the same horseshoe crab. Using MRI, a virtual dissection can be performed while keeping the specimen intact [Persson et al., 2011]. MR images were recorded in Digital Imaging and Communication in Medicine (DICOM) format in the present study. DICOM data sets can be permanently stored in Picture Archiving and Communication System (PACS), which can be recalled at will to the same specimen if additional information is required. Its digitally transferable feature can also facilitate second opinion by other professionals or institutes worldwide even if the specimens cannot not be physically provided or available.

Another major advantage of the MRI is the ability to produce a range of $3 \mathrm{D}$ reconstructions, allowing for a better understanding of the internal anatomy of the specimen. Tri-spine horseshoe crab examined in this way may provide a useful way of visualizing the spatial arrangement of internal anatomical structures. While the present study intended to depict anatomical structures of the tri-spine horseshoe crab on planimetric MR images, illustration of 3D anatomical structures should be included for consideration in future research of trispine horseshoe crab.

The present study is the first to depict the anatomical structures of live tri-spine horseshoe crab using MRI. The result demonstrated that $\mathrm{T} 1 \mathrm{~W}$ and $\mathrm{T} 2 \mathrm{~W}$ sequences can produce MR images with sufficient contrast to allow the identification of a broad selection of anatomical structures in the live tri-spine horseshoe crab. The illustrations in the present study provide an initial reference to evaluate anatomical structures of the live tri-spine horseshoe crab on MR images. It could be considered as a useful alternative for biologi- 

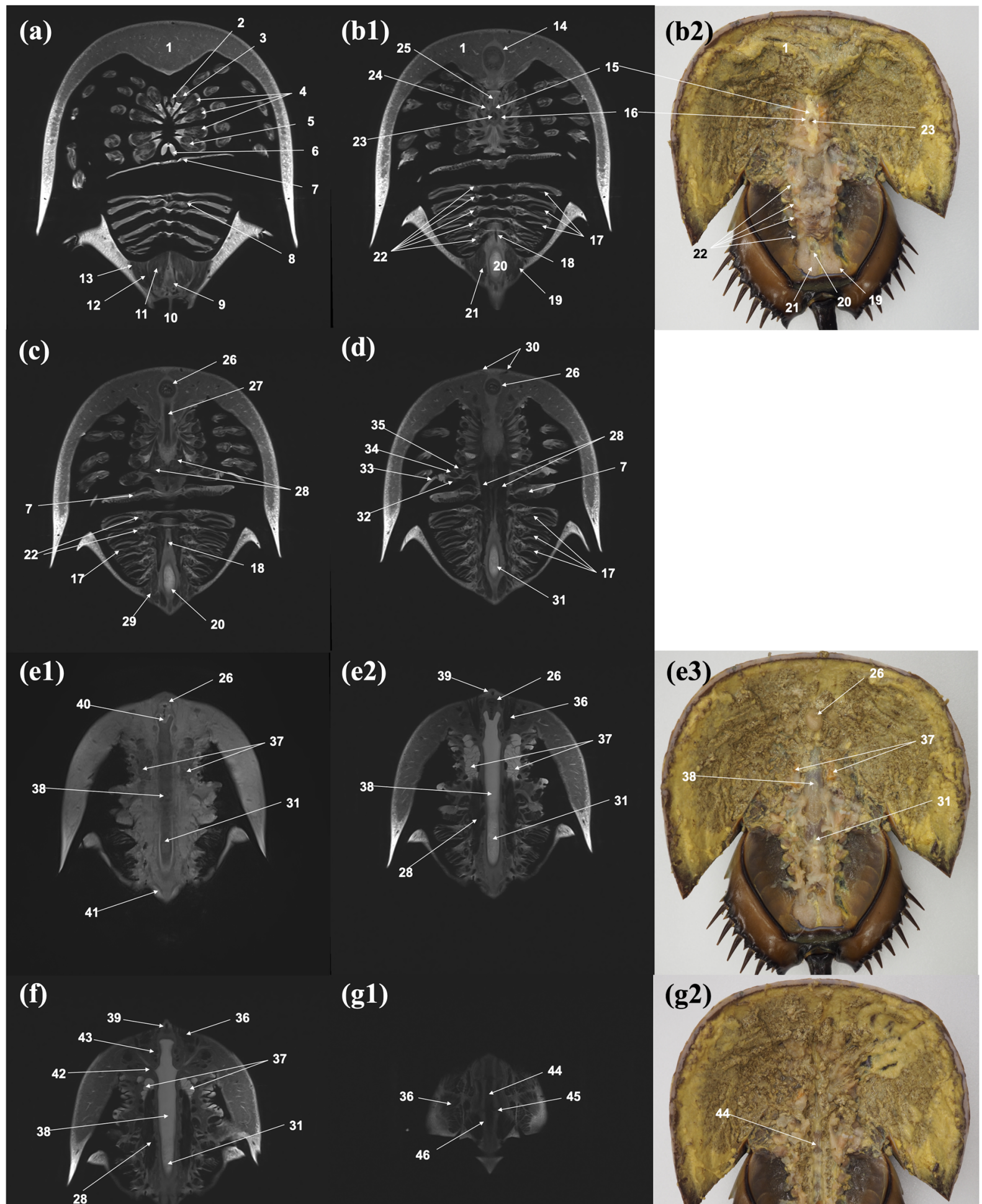

(g1)

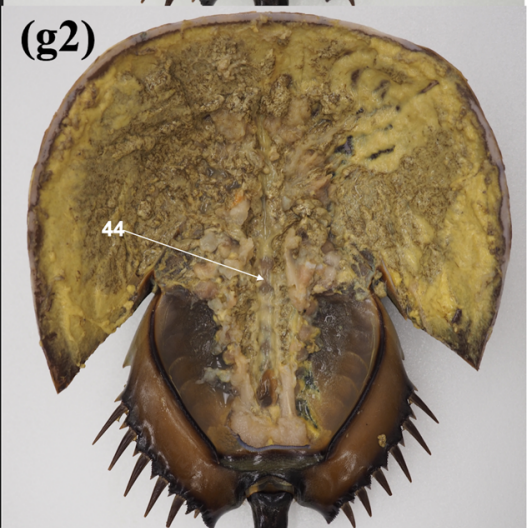

Fig. 2. Coronal MR images and corresponding dissection images of Tachypleus tridentatus at different levels of Figure 1: (a) T2W image at level 1; (b) T2W image (b1) and corresponding dissection image (b2) at level 2; (c) T2W image at level 3; (d) T2W image at level 4; (e) T1W image (e1), T2W image (e2), and corresponding dissection image (e3) at level 5; (f) T2W image at level 6; (g) T2W image (g1) and corresponding dissection image (g2) at level 7. 
cal and paleontological investigation of the tri-spine horseshoe crab in the future.

Acknowledgements. The authors are grateful to the Time Medical Systems Ltd. for providing access to their 1.5T MRI scanner. Sincere appreciation is also extended to Miss Cherry Tsz Ching Poon for nursing care of animals and post-processing of MR images in the present study. Special thanks to Dr. Jason $\mathrm{Wu}$ for English editing of this manuscript.

\section{References}

Bergdale K.J. 2017. Illustrations for Health Assessment Techniques of the Atlantic Horseshoe Crab, Limulus polyphemus. Doctoral dissertation, Johns Hopkins University.

Berquist R.M., Gledhill K.M., Peterson M.W., Doan A.H., Baxter G.T., Yopak K.E., Kang N., Walker H.J., Hastings P.A., Frank L.R. 2012. The Digital Fish Library: using MRI to digitize, database, and document the morphological diversity of fish // PLoS One. Vol.7. No.4. e34499.

Bicknell R.D., Klinkhamer A.J., Flavel R.J., Wroe S., Paterson J.R. 2018. A 3D anatomical atlas of appendage musculature in the chelicerate arthropod Limulus Polyphemus // PloS one. Vol.13. No.2. e 0191400 .

Brouwer M., Engel D.W., Bonaventura J., Johnson G.A. 1992. In vivo magnetic resonance imaging of the blue crab, Callinectes sapidus: effect of cadmium accumulation in tissues on proton relaxation properties // Journal of Experimental Zoology Part A Ecological Genetics and Physiology. Vol.263. No.1. P.32-40.

Dewey M.M., Levine R.J., Colflesh D.E. 1973. Structure of Limulus striated muscle: the contractile apparatus at various sarcomere lengths // The Journal of cell biology. Vol.58. No.3 P.574-593.

Havsteen I., Ohlhues A., Madsen K.H., Nybing J.D., Christensen H., Christensen A. 2017. Are Movement Artifacts in Magnetic Resonance Imaging a Real Problem?-A Narrative Review // Frontiers in neurology. Vol.8. P.232.

Herberholz J., Mims C. J., Zhang X., Hu X., Edwards D.H. 2004. Anatomy of a live invertebrate revealed by manganese-enhanced Magnetic Resonance Imaging // Journal of Experimental Biology. Vol.207. No.26. P.4543-4550.

Köhnk S., Baudewig J., Brandis D., Boretius S. 2017. What's in this crab? MRI providing high-resolution three-dimensional insights into recent finds and historical collections of Brachyura // Zoology. Vol.121. P.1-9.
Lauridsen H., Hansen K., Wang T., Agger P., Andersen J.L., Knudsen P.S., Rasmussen A.S., Uhrenholt L., Pedersen M. 2011. Inside out: modern imaging techniques to reveal animal anatomy // PLoS One. Vol.6. No.3. e17879.

Michael Holliman F., Davis D., Bogan A.E., Kwak T.J., Gregory Cope W., Levine J.F. 2008. Magnetic resonance imaging of live freshwater mussels (Unionidae) // Invertebrate biology. Vol.127. No.4. P.396-402.

Nolan M.W., Smith S.A. 2009. Clinical evaluation, common diseases, and veterinary care of the horseshoe crab, Limulus Polyphemus // Biology and conservation of horseshoe crabs. Boston, MA: Springer. P.479-499.

Persson A., Lindblom M., Jackowski C. 2011. A state-of-the-art pipeline for postmortem CT and MRI visualization: from data acquisition to interactive image interpretation at autopsy // Acta Radiologica. Vol.52. No.5. P.522-536.

Pouvreau S., Rambeau M., Cochard J.C., Robert R. 2006. Investigation of marine bivalve morphology by in vivo MR imaging: first anatomical results of a promising technique // Aquaculture. Vol.259. P.415-423.

Sigl R., Imhof H., Settles M., Laforsch C. 2013. A novel, noninvasive and in vivo approach to determine morphometric data in starfish // Journal of experimental marine biology and ecology. Vol.449. P.1-9.

Silvey G.E. 1973. Motor control of tail spine rotation of the horseshoe crab, Limulus Polyphemus // Journal of Experimental Biology. Vol.58. No.3. P.599-625.

Smith P.T., Reddy N. 2012. Application of magnetic resonance imaging (MRI) to study the anatomy and reproductive condition of live Sydney rock oyster, Saccostrea glomerata (Gould) // Aquaculture. Vol.334. P.191-198.

Van der Hoeven J. 1838. Recherches sur l'histoire naturelle et l'anatomie des limules. Leyde: Chez S. \& J. Luchtmans. 48 p. + VII pl.

Ward D.V. 1969. Leg extension in Limulus // The Biological Bulletin. Vol.136. No.2. P.288-300.

Watson W.H. 1980. Limulus gill cleaning behavior // Journal of comparative physiology. Vol.141. No.1. P.67-75.

Ziegler A., Faber C., Mueller S., Bartolomaeus T. 2008. Systematic comparison and reconstruction of sea urchin (Echinoidea) internal anatomy: a novel approach using magnetic resonance imaging // BMC biology. Vol.6. No.1. P.33.

Ziegler A., Kunth M., Mueller S., Bock C., Pohmann R., Schröder L., Faber C., Giribet G. 2011. Application of magnetic resonance imaging in zoology // Zoomorphology. Vol.130. No.4. P.227-254

Responsible editor K.G. Mikhailov

Abbreviations: 1 - hepatopancreas and gonadal tissue, 2 - chelicera (first prosomal appendage), 3 - pedipalp (second prosomal appendage), 4 - walking leg (third to fifth prosomal appendages), 5 - swimmer leg (sixth prosomal appendage), $6-$ chilariae, $7-$ genital operculum, 8 - gill operculum, $9-$ anus, $10-$ telson, $11-$ medioventral head telson depressor, $12-$ lateroventral telson depressor, 13 - telson abductor, 14 - crop, 15 - protocerebrum, 16 - tritocerebrum, 17 - book gills, 18 - coelomic artery, $19-$ lateral telson leviator, 20 - rectum, 21 - medial telson leviator, 22 - remotor muscle and promotor muscle of gill operculum, $23-$ mouth, 24 - lateral optic nerve, 25 - median optic nerve, 26 - gizzard, 27 - esophagus, 28 - longitudinal muscle, 29 - telson muscle, 30 - anterior marginal artery, 31 - hindgut, 32 - posterior trochanter depressor, 33 - flabellum, 34 - anterior trochanter depressor, 35 trochanter levator, 36 - leg muscle attachment, 37 - convoluted tubule, 38 - midgut, 39 - frontal artery, 40 - pyloric valve, 41 colateral artery, 42 - glandular hepatic ceca, 43 - cephalic artery, 44 - heart, 45 - lateral cardiac artery, 46 - pericardial cavity.

Рис. 2. Корональные изображения, полученные при помощи магнитного резонанса, и соответствующие иллюстрации по обычным срезам мечехвоста Tachypleus tridentatus на различных уровнях, указанных на Рис. 1: (a) T2W-изображение на уровне 1; (b) T2W-изображение (b1) и соответствующий срез (b2) на уровне 2; (c) T2W-изображение на уровне 3; (d) T2W-изображение на уровне 4; (e) T1W-изображение (e1), T2W-изображение (e2), и соответствующий срез (е3) на уровне 5; (f) T2W-изображение на уровне 6; (g) T2W-изображение (g1) и соответствующий срез (g2) на уровне 7.

Обозначения: 1 - печень и ткань гонад, 2 - хелицера (1-й придаток просомы), 3 - педипальпа (2-й придаток просомы), 4 ходная нога (3-5-й придатки просомы), 5 - плавательная нога (6-й придаток просомы), 6 - хилярии, 7 - половая крышка, 8 легочная крышка, 9 - анус, 10 - тельсон, 11 - медиовентральное основание депрессора тельсона, 12 - латеровентральный депрессор тельсона, 13 - абдуктор тельсона, 14 - зоб, 15 - протоцеребрум, 16 - тритоцеребрум, 17 - легочные книжки, 18 целомическая артерия, 19 - латеральный левиатор тельсона, 20 - прямая кишка, 21 - срединный левиатор тельсона, 22 ремотор и промотор легочной крышки, 23 - рот, 24 - латеральный глазной нерв, 25 - срединный глазной нерв, $26-$ мускульный желудок, 27 - пищевод, 28 - продольная мышца, 29 - мышца тельсона, 30 - передняя краевая артерия, 31 задняя кишка, 32 - задний депрессор вертлуга, 33 - флабеллюм, 34 - передний депрессор вертлуга, 35 - леватор вертлуга, 36 крепление мышцы ноги, 37 - половая трубка, 38 - средняя кишка, 39 - фронтальная артерия, 40 - кардиальный клапан, 41 коллатеральная артерия, 42 - железеистые выросты печени, 43 - головная артерия, 44 - сердце, 45 - боковая сердечная артерия, 46 - околосердечная полость. 